\title{
The Quintessence of Organizational Commitment and Organizational Cynicism
}

\begin{abstract}
The article deals with the constituents of organizational commitment and organizational cynicism and in order to concisely present systematised material disclosing the very essence of the phenomena, the authors analyse their interrelation, the specificity of development (organizational commitment) and management (organizational cynicism), their causes, importance and / or consequences caused. The aim of research is to distinguish the dimensions of the relationship of these phenomena highlighting the quintessence of organizational commitment and organizational cynicism.
\end{abstract}

Keywords: organizational commitment, affective commitment, continuance commitment, normative commitment, organizational cynicism, affective cynicism, cognitive cynicism, behavioural cynicism.

Straipsnyje, siekiant glaustai pateikti susistemintą medžiagą, kuri atskleistų pačią reiškinių esmę, analizuojamos organizacinio ịsipareigojimo ir organizacinio cinizmo dedamosios, jų tarpusavio ryšiai, vystymo (organizacinis Ł̇sipareigojimas) ir valdymo (organizacinis cinizmas) specifika, priežastys, svarba ir / arba sukeliami padariniai. Šio tyrimo tikslas - išnagrinèti organizacinio įsipareigojimo ir organizacinio cinizmo kvintesenciją.

Raktiniai žodžiai: organizacinis ịsipareigojimas, emocinis ịsipareigojimas, tęstinis ịsipareigojimas, norminis i̊sipareigojimas, organizacinis cinizmas, emocinis cinizmas, kognityvinis cinizmas, elgesio cinizmas.

\section{Introduction}

Relevance of research. Organizational commitment and organizational cynicism are two phenomena relevant for organisations and widely analysed, which can have very distinct positive and negative consequences that either help the organization to grow or lead it to failures. Organizational commitment identifies a tight relationship of the employee with the organisation in which he works (Naude et al., 2003), shows the degree of the individual's organisational identification (Newstrom, 2015), the level of the person's identification and his engagement in the organization (Naqvi et al., 2013), in which he seeks to further continue working, as well as discloses the psychological state of the person who particularly relates himself to the organization (Garg, 2017). In any case, organizational commitment transmits the employee's attachment to the organization. As H. L. Angle and J. L. Perry $(1981,1983)$ note, this is a positive link, economic interchange between

Aida MARGELYTÉ-PLESKIENĖ - Master of Social Sciences (Management), Department of Management, Faculty of Economics and Management, Vytautas Magnus University, Lithuania. Address: S. Daukanto Str. 28, LT-44246 Kaunas, Lithuania. Tel. +370 638 76034. E-mail: aida.margelyte-pleskiene@stud.vdu.lt.

Jolita VVEINHARDT - Doctor of Social Sciences (Management), professor at the Department of Management, Faculty of Economics and Management, Vytautas Magnus University, Lithuania. Address: S. Daukanto Str. 28, LT-44246 Kaunas, Lithuania. Tel. + 370698 06668. E-mail: jolita.vveinhardt@vdu.ltn 
the organization and the employee, perceived through the prism of an obligation to stay in the organization. The analysis of organizational commitment and organizational cynicism highlight certain dimensions that link both phenomena. It is generally believed that the cynical attitude forms employees' degrading and critical behaviour, which accordingly also determines a reduced level of effort (Dean et al., 1998). Cynical employees are less attached to the organization, and their dissatisfaction leads them to the belief that they will not work in the organization for a long time (Kim et al., 2009). In addition, cynical employees are less inclined to assume additional responsibilities in the organization. Although the concept of cynicism in various fields has been analysed for a long time, research related to organizational cynicism was begun only in the ninth decade of the $20^{\text {th }}$ century (Terzi and Derin, 2016). In addition, conceptualisation of organizational cynicism poses problems due to the complexity of the process; therefore, there is a variety of definitions of organisational cynicism (Naus, 2007). Organizational cynicism is related to employees' negative feelings, such as despair, contempt and hopelessness assessing their organization, its managers and other objects of the workplace (Cole et al., 2006). J. W. Dean et al. (1998) characterize such negative attitude of employees as an inclination to tendentious despair, critical and negative anti-organizational activities and a belief that the organisation lacks integrity.

In order to ensure their good performance and successful development, organizations, at their discretion, must respectively find the most appropriate ways to increase organizational commitment and decrease the level of employees' cyni- cism with regard to the organization. In order to do this properly, first, it is necessary not only to perceive the meaning of organizational commitment but also to find out what causes determine the emergence of organizational cynicism as well as to understand the consequences the organization can have if this problem is not resolved in a timely manner.

The problem of research. One of the most appropriate ways to help to prevent the employee from the intentions to leave his/her organization is his/her commitment, which is a widely discussed phenomenon solving the problems of the employee's retention at the workplace. Another, still not so abundantly analysed phenomenon, compared with organizational commitment, is organizational cynicism, the growth of which in the organization determines the decrease of the first phenomenon - organizational commitment. Therefore, the problem of the research is raised by the question: what are the quintessential features of organizational commitment and organizational cynicism and how, through what organizational dimensions do they interact?

The level of problem exploration. Organizational commitment due to its importance and organizational cynicism due to its problems are the phenomena widely studied by foreign scientists.

Organizational commitment. A large number of scientists devote attention to the diagnostics of organizational commitment; several of them should be mentioned: types of organizational commitment are analysed by P. C. Morrow (1983), A. Cooper-Hakim and C. Viswesvaran (2005) and others; the benefit of organizational commitment is disclosed in the research of M. F. Faisal and B. A. Esmael (2014), H. Paul et al. (2016) and others; the chronological sequence of 
the concept of organizational commitment and the interactions of aspects, factors of employees' commitment to the organization are grounded by Ž. Kavaliauskienè (2011) and others. The relationship of organizational commitment with other organizational phenomena, such as: job satisfaction (Porter et al., 1974; Lambert et al., 1999; Naqvi et al., 2013; Yang and Lee, 2016; Benevene et al., 2018; etc.), work values (Chin-Chih, 2006), job involvement (Chin-Chih, 2006), social responsibility (Yang and Lee, 2016; Allen et al. 2017; etc.), leadership (transactional leadership: Afshari and Gibson, 2016; transformational leadership: Allen et al. 2017; ethical leadership (Benevene et al., 2018; etc.), wellbeing (Maltin and Meyer, 2010; Dhondt et al., 2014; Schulz et al., 2017; etc.), professional competency (Karami et al., 2017), job choice, job autonomy, organizational identification is investigated by C. A. O'Reilly and D. F. Caldwell (1980), S. R. Naqvi et al. (2013), G. W. Allen et al. (2017) and others.

Organizational cynicism. So far, there is not particularly much research on this phenomenon (compared with the research on organizational commitment published in the WoS database), for example, in the WoS database (during the period from 1990 to 2018), searching by title and the keywords "organizational cynicism", as of 2018-12-04, the statistics is as follows: 1998 - 1 publication, $2000-2$ publications, $2002-1,2003-1,2004-2$, 2005 - 2, 2007 - 2, 2008 - 5, 2009 - 1, 2010 - 2, $2011-2,2012$ - 1, $2013-6$, 2014 - 7, 2015 - 4, 2016 - 8, 2017 - 11, 2018 - 10. Thus, the types of cynicism are analysed in research by J. W. Dean et al. (1998) and others; preconditions for the formation of cynicism were studied by M. Schraeder et al. (2016), J. A. Abugre (2017), I. Topcu et al. (2017) and oth- ers; the kinds of cynicism are detailed by J. W. Dean et al. (1998), T. J. Kim et al. (2009) and others; the causes of cynicism are discussed by J. L. Johnson and A. M. O'Leary-Kelly (2003), D. S. Chiaburu et al. (2013), S. Aslan and S. Eren (2014) and others; the consequences of cynicism for the organisation are distinguished by R. Abraham (2000), P. Brandes et al. (2008), S. R. Naqvi et al. (2013) and others; the consequences of cynicism for the employee emphasized C. Maslach (2003), A. R. Terzi and R. Derin (2016) and others. There was also analysed the relationship of organizational cynicism with other organizational phenomena such as: value incongruence, job autonomy, loyalty (Naus et al., 2007a, 2007b; etc.), leadership (Schilling, 2008; Felfe, 2008; Rubin et al., 2009; Mete, 2013; Polatcan, Titrek, 2014; Gkorezis et al., 2014; etc.), perceived organizational support and performance (Byrne, Hochwarter, 2008; etc.), organizational citizenship behaviour (Wilkerson et al., 2008; etc.), perceived corporate citizenship (Evans et al., 2011), job satisfaction (Arabaci, 2010), employee deviance (Evans et al., 2011), job insecurity (Cinar et al., 2014), job burnout (Simha et al., 2014), perceived organizational support (Kasalak, Aksu, 2014), organizational commitment (Han et al., 2013), and others. Nevertheless, there exists a lack of research that closely addresses organizational commitment and organizational cynicism; therefore, there is a relevant need for highlighting and defining the dimensions of the relationship of these phenomena.

The object of research: phenomena of organizational commitment and organizational cynicism.

The aim of research: upon highlighting the quintessence of organizational 
commitment and organizational cynicism, to distinguish the dimensions of the relationship of these phenomena.

\section{Objectives of research:}

1. To analyse the essence of organizational commitment for the employee-organization and the possibilities of increasing it.

2. To analyse the essence of the phenomenon of organizational cynicism, causes of its emergence and the consequences for the employee-organization relation.

3. To distinguish the dimensions of the relationship of organizational commitment and organizational cynicism.

Methods of research. In the first part of the study, scientific research from the Web of Science Core Collection (Clarivate Analytics), Scopus and other scientific databases was selected; in the second part, the analysis and synthesis of scientific literature was conducted, also there were applied the methods of analogy, chronology and comparison.

\section{The significance of organizational commitment for an employee- organization relation and the possibilities to increase it}

The phenomenon of organizational commitment is analysed by scientists of psychology, management and other fields. The description of the phenomenon "organizational commitment" is presented as acceptance of the organization's aims and values, a clear willingness to maintain organizational dependence and a resolve to make a considerable effort in the name of the organization (Porter et al., 1974).

N. J. Allen and J. P. Meyer (1990), who presented an integrated approach to or- ganizational commitment, analysing this phenomenon, pointed out that it can be defined by three components: affective, continuance, and normative commitment. Affective commitment is acknowledged as the strongest and most persistent indicator for the organization that seeks to implement aims and achieve results. Based on M. S. Lampinen et al. (2017), employees with strong affective commitment remain with the organization because they want it; employees with strong continuance commitment remain in the organizations because they have to do so; employees with strong normative commitment remain in the organizations because they feel they must do so. S. Jiang et al. (2018) supplement these thoughts pointing out that affective commitment means that employees create a relationship with their organization, continuance commitment is created when it is too costly for employees to leave the organization for financial or moral reasons, and in the case of normative commitment employees cannot leave the organization due to the sense of responsibility they feel for the organization that employed them.

According to M. Franco and S. Franco (2017), in recent years, there has been a marked increase in research on organizational commitment and its bases. According to the authors, this growth manifested itself due to the academicians' and managers' interests seeking to understand the relationships existing between the organization and the employees. It is highlighted that organizational commitment attracts both researchers' and practitioners' attention due to its positive impact on the organization and the employee (Maltin and Meyer, 2010). To understand what has the greatest influence on organizational commitment, this phenomenon is compared 
with various other phenomena revealing employees' well-being. Employees' wellbeing is perceived as factors affecting employees' health, quality of work environment and other characteristics related to workplace: employment, staff retention, training and other forms of involvement (Schulz et al., 2017). Employees who feel well-being at the workplace tend to be more committed to their organization.

As D. F. Caldwell et al. (1990) point out, although the literature on organization's psychology devoted much attention to the construct of organisational commitment, anyway, the focus was on the aspiration to identify the benefit to the organization if its employees are strongly engaged in executed activities. Meanwhile, the significance of commitment to the very employee is studied considerably less. Based on J. S. Adams' (1963) equity theory, the employee is interested in having a fair and equitable relation with the organization, while perceived injustice results in dampening motivation and, conversely, perceived organizational justice can increase the employee's motivation as the employee will feel obligated to maintain a corresponding relation between him and the organization (LazauskaiteZabielske et al., 2014). For this reason, the importance of organizational commitment will be further discussed, analysing it both from the organization's and the employees' perspective.

The benefit of organizational commitment to the organization. Analysing the phenomenon from the organization's perspective, it can be observed that a high level of commitment positively affects the organization, as it encourages employees to work better and focus stronger on the goal (Jiang et al., 2018). According to M. Franco and S. Franco (2017), em- ployees who are committed to the organization believe that their behaviour at work must be appropriate and moral. Organizational commitment is also an important factor assessing the employee's willingness to contribute to the organization's goals (Memili et al., 2013). P. Naude et al. (2003) highlight that it takes time for employees to analyse the organization, its values and expectations and to relate all of these aspects to their own needs, benefit obtained or potential perspectives. However, the more employees are satisfied and the more strongly they associate themselves with the organization, the more positive they are with regard to the common goals of the organization.

Various scientific research indicates that committed employees tend to become more involved and support their organization (Paul et al., 2016). Such factors as the feeling of belonging, mutual trust and assessment, open communication with colleagues, and open sharing of information in the organization are also associated with organizational commitment (Lampinen et al., 2017). In addition, committed employees make a more meaningful personal contribution and better perform their functions at the workplace (Bangval et al., 2017), which results in greater intensity of work (Angle and Perry, 1981). Besides, employees' commitment enhances socially active behaviour (O'Reilly and Chatman, 1986) and loyalty (O'Reilly and Caldwell, 1980). Thus, interacting with each other, all phenomena create shared benefit for the organization and its successful activities.

Finally, various studies confirm the fact that employees' commitment to the organization gives a consistent competitive advantage (Jena et al., 2017). Employees with a higher level of organizational 
commitment are less likely to look for alternate job offers, and it results in fewer errors at work. It is stated that work environments, which are strongly oriented towards achievement of goals and which promote a higher level of organizational commitment, have less conflict situations at work (Halbesleben and Tolbert, 2014). In addition, employers themselves value employees' commitment and loyalty, because such employees perform tasks better and are known for lower levels of absence (Mathieu and Zajac, 1990).

The benefit of organizational commitment to the employee. Analysing the organizational commitment phenomenon from the employees' perspective, first it can be pointed out that committed employees feel the meaningfulness of work and gratitude from managers, which respectively determines their greater efforts and better results (Lampinen et al., 2017). In other words, employees' job satisfaction can increase their commitment to the organization (Bangval et al., 2017). Research conducted by K. Kotze and G. Roodt (2005) confirms that there is a strong positive relationship between employees' job satisfaction and employees' commitment to their organization, because alongside with the increasing employee job satisfaction, their commitment to the organization increases $\mathrm{(Mu}-$ eller et al., 1994). In addition, the employees are also greatly concerned about the organization's commitment to them, because if the organization appreciates them, this results in both financial (salary, promotion) and non-financial benefit (respect, approval).

Employees' commitment is also influenced by career opportunities created at the workplace (Moon and Choi, 2017). It has been found that career-oriented com- mitment can be an antecedent of organizational commitment. Employees' successful career can be beneficial to organizations; therefore, it is relevant to them to ensure employees' career development opportunities. The more the organization appreciates a particular profession, the more the interface between the career and organizational commitment enhances (Bagraim, 2003). According to A. Basak Ok and C. Vandenberghe (2016), bearing in mind that people nowadays are highly concerned about their employment and careers, their career-oriented commitment can be as a beneficial form of affective commitment to the organization, which also generates benefit for the employee himself. Employee commitment is a necessary factor seeking the organization's growth and to increase employees' motivation (Ajgaonkar et al., 2012). By their emotional attachment employees pay back to the organization for its commitment and care about them. As it has already been explained, for the employee himself commitment helps to discover the meaning of work, job satisfaction, creates not only financial but also emotional benefit.

Possibilities of increasing organizational commitment. In the scientific literature, various authors present different solutions that can help to increase organizational commitment. S. Jiang et al. (2018) distinguish the benefit of formalizing rules and clearness of employees' workplace, the importance of autonomy at work, integration in the workplace, stress management, organizational justice and provision of additional benefits to employees as well as the impact of employees' work engagement and job satisfaction on increasing of organizational commitment. Organizational climate is also very important seeking organizational commit- 
ment (Bahrami et al., 2016). The authors point out that organizational climate ensures the relationship between leaders and the organization itself. The variables of organizational climate such as motivation, decision-making, communication, leadership and goal setting are significant prerequisites for the formation of organizational commitment.

Other authors point out that affective commitment is enhanced by employees' engagement in decision making (Jena et al., 2017). Employees are very appreciative when their proposals are listened to. A. Suliman and P. Iles (2000) explore increasing of continuance commitment by providing additional benefits to employees. Benefit particularly increases continuance commitment, as the cost of leaving the organization is high to employees, which determines their greater engagement and willingness to stay in the organization. Among other solutions, G. Togna (2014) indicates promotion of internal communication, which contributes to increasing of trust and commitment. L. Afshari and P. Gibson (2016) analyse the importance of leadership. The authors point out that leaders' behaviour and support are important for employees: this promotes better quality work and employees' greater satisfaction with obtained results. The importance of leaders' support is also emphasised by K. A. Scott and D. Zweig (2016). In addition, one type of leadership is distinguished: transformational leadership, which has a positive effect on affective and normative commitment (Allen et al., 2017). Strong and positive relation between transformational leadership and affective commitment is formed on the basis of motivating employees through emotions, the leader's persuasive vision for employees to work together for the sake of the collective.

To sum up, it can be stated that organizational commitment is related to and influences various different determinants of organizational success, such as: organizational citizenship behaviour, job involvement, job satisfaction, a sense of belonging to the organization, mutual trust and appreciation, open communication, open dissemination of information within the organization, assurance of meaningfulness of work, etc. Promotion of the development of the said constituents ensures the overall benefit of organizational commitment for both the organization and the employee.

\section{The causes of organizational cynicism and its consequences for the employee/organization}

The phenomenon of organizational cynicism is abundantly analysed by scholars of various fields and trends (Dean et al., 1998; Wanous et al., 2000; Abraham, 2000; Sak, 2018; Archimi et al., 2018; Li, Chen, 2018; Mignonac et al., 2018; Gokyer, Turkoglu, 2018; Mousa, 2018; Munir et al., 2018; Gkorezis et al., 2018; Schmitz et al., 2018; etc.). The very description of the phenomenon "organizational cynicism" is presented as an attitude that is formed by the trends of faith, feelings and behaviour. Authors (Dean et al., 1998; Kim et al., 2009; Terzi, Derin, 2016) distinguish three types of organizational cynicism: behavioural, cognitive, and affective. Cognitive cynicism exists when employees think that the organization does not care about them and that it does not appreciate their contribution. In the employees' opinion, the organization practices injustice, dis- 
honesty and insincerity. Affective cynicism encompasses emotional reactions such as irritation, tension and anxiety, dissatisfaction, anger, pain or confusion. Such feelings reduce motivation and commitment to the organization. Behavioural cynicism manifests itself by negative and degrading behaviour: organizational criticism, sarcastic humour, negative non-verbal behaviour, cynical interpretations of activities carried out in the organization, pessimistic predictions of the organization's activities and future plans.

Causes of cynicism. Numerous studies in scientific literature deal with the causes of emergence of organizational cynicism (Dean et al., 1998; Johnson, O’Leary-Kelly, 2003; Chiaburu et al., 2013; Aslan, Eren, 2014; Topcu et al., 2017; etc.). Causes may be induced by the organization itself or personality traits. When analysing the organizational factors that determine cynicism, it is pointed out that in most cases, manifestations of the organizational cynicism attitude are directed to top executives who poorly represent the organization (Byrne, Hochwarter, 2008). Organizational cynicism is defined by the lack of trust in management, the belief that managers make use of their employees (Aslan, Eren, 2014). In addition, cynicism particularly increases if employees feel the managers' greed, their unethical behaviour in the organization, high-level competition (Dean et al., 1998), managers' irritation or irritability (Johnson, O’Leary-Kelly, 2003) or if they envisage that managers act only considering the organizational benefit of business and that such management will not be changed in the future (Dean et al., 1998; Aslan, Eren, 2014). In other words, employees may think that management is incapable to meet their expectations or that the management itself chooses not to meet the employee's expectations and, therefore, cannot be trusted (Wanous et al., 2000; Cole et al., 2006). Finally, cynicism is promoted by the lack of the manager's assistance, leaders' hypocrisy (Johnson, O’Leary-Kelly, 2003).

One of the most important and most emphasized causes of cynicism is the named psychological contract violation that not only harms employer-employee relationships but also further leads to employee's disappointment and distrust in organizations (Cartwright, Holmes, 2006). The psychological contract violation causes employees' negative attitude and negative behaviour towards their organization (Kuang-Man, 2013). The impact of the psychological contract violation is much stronger than the stakeholders' expectations because it reduces employees' job satisfaction and increases willingness to leave the organization. Cynical employees have doubts about the fairness of the information provided to them in the organization, and they feel exploited for better results of the company, which results in the loss of employees' trust in the organization and its management.

Another widely studied cause of organizational cynicism is organizational change, since organizational problems and crises caused by unsuccessful implementation of organizational change objectives and bad outcomes result in a particularly high increase of cynicism (Aslan, Eren, 2014; Ozer et al., 2014; Topcu et al., 2017; etc.). Cynical feelings about change particularly increase if the attempts of earlier change were unsuccessful or if new ineffective change programs are constantly proposed in the organisation (Bernerth et al., 2007). For these reasons, cynical employees have doubts about their mangers' declarations (Reichers et al., 1997). It is 
very important to assess whether employees clearly perceive the importance of future changes. If employees do not believe or do not understand what results of change are to be achieved, they will clearly demonstrate resistance, which comes to prominence in the form of cynicism. If leaders lack fairness while implementing organizational change, it is also likely that employees will be disappointed, angry and cynical (Bernerth et al., 2007). Finally, it is important to note that even if there were mistakes in the implementation of organizational change or wrong information was provided to employees, the cynicism of the organization's employees can be reduced by simply acknowledging the mistakes made (Schraeder et al., 2016). Any involvement of employees and sharing of information is significant seeking a more open attitude in the implementation of organizational change.

Finally, it is important to point out that although cynicism often results from unsuccessful organizational change, it is also a major barrier to organizational change programs (Aslam et al., 2016). Cynical employees generally do not tend to believe in change and its importance and significance. P. Brandes et al. (2008) emphasize that various studies confirm the impact of cynicism on employees' attitude to change taking place in the organization. Such employee cynicism has two main elements: employees pessimistically assess the success of change and blame responsible persons for the lack of motivation (Wanous et al., 2000). Thus, cynical employees negatively assess organizational change; and even if employees accept change, but it is unsuccessful, as a consequence, eventually, organizational cynicism is anyway induced.
Another important antecedent that causes organizational cynicism is the lack of autonomy and independence at work (Naqvi et al., 2013). If employees feel separated from decision-making while working, their job satisfaction decreases with time, they become cynical and less committed to their organization. S. Shaharruddin and F. Ahmad (2015) state that provision of autonomy in the workplace can help to reduce cynicism. This is very important in the context of another, the already discussed cause of cynicism organizational change. Employees are more inclined to be cynical with regard to change when they lack significant opportunities to participate in decisionmaking or if they are not informed what is happening at their workplace in general (Bernerth et al., 2007). For this reason, organizations seeking to reduce cynicism and ensure the greater employee involvement should focus on organizational empowerment by giving employees greater freedom to make independent decisions and make greater influence on their work (Abdullah et al., 2015).

It can be seen that scientific literature presents many and different attitudes to the causes of the emergence of organizational cynicism. This list is supplemented by M. S. Cole et al. (2006), who state that the main causes of cynicism are perceived organizational support, poor administrative competency, distrust in administration and work environment. A. J. Naus et al. (2007a, 2007b) note that organizational cynicism is caused by insufficient social support, insufficient promotion, goal conflicts, increasing organizational complexity, failure to keep promises, inability to make efficient decisions, ineffective communication or lack of it, unfair distribution of power, absence of justice (Bommer et al., 2004). 
Other sources of dissatisfaction contributing to the growth of employees' negative attitude are scandals in the organisation, wasted funds of the company (Johnson, O’Leary-Kelly, 2003), role conflict in the organization, high hierarchy, inequality, long working hours, redundancies, confusing internal policy, unethical behaviour, week interaction between organizational results, the manager and employee (Davis, Gardner, 2004). Cynicism is also promoted by the lack of resources, high level of stress, the belief that managers get unreasonably high salaries, the perception that job requirements are too high (Schraeder et al., 2016). When employees perceive that the company satisfies only its needs and is oriented only to its expectations, their cynicism with regard to the organization gradually increases. Dissatisfaction with personal and organizational expectations, high-level competition, goal conflict, increased level of organizational chaos can also induce cynicism (Ozer et al., 2014).

Organizational cynicism can be caused not only by organizational but also by personal factors. Such named factors are age, gender, marital status, seniority, income, education, professional status, as well as anxiety, distrust, disappointment and humiliation (Terzi, Derin, 2016). D. S. Chiaburu et al. (2013) also mention that demography, the employee's previous positive or negative experience can be considered the antecedents of cynicism. Thus, it can be assumed that organizational cynicism is more often the result of the organization itself and not of the person's personal traits.

The consequences of cynicism for the organization. As pointed out by S. R. Naqvi et al. (2013), organizational cynicism is one of the main problems hin- dering to achieve organizational goals and success; therefore, the number of studies on organizational cynicism is increasing, as it is important for organizations to understand not only the causes of organizational cynicism but also the consequences induced. The conducted research confirmed the negative impact of cynicism on work results, assessing them both at the individual and organizational level (Brandes et al., 2008).

Organizational cynicism is related to many negative and undesirable results, such as low level of satisfaction and commitment, poor civic behaviour (Johnson, O'Leary-Kelly, 2003), employee turnover (Aslam et al., 2016). Decreased job satisfaction, the absence of organizational commitment and public spirit give rise to negative consequences: employees' disappointment with work is increasing (Terzi, Derin, 2016, qtd. in Abraham, 2000). In other words, the employee's cynicism is negatively related to motivation for work (Wanous et al., 2000). Studies demonstrated that the consequences of organizational cynicism might manifest themselves by passive participation in the activities of the organization, poor performance, low level of morals, and high absenteeism (Johnson, O'Leary-Kelly, 2003). There are also many studies that prove that cynicism has a negative impact on employees' loyalty, motivation and teamwork continuity (Ozer et al., 2014), since cynical employees do not trust others, they are less helpful (Kim et al., 2009; West et al., 2015; Terzi, Derin, 2016; Collins, 2017; etc.).

The consequences of cynicism for the employee. Analysing the consequences of cynicism for the employee, based on various studies, Terzi and Derin (2016) state that organizational cynicism gives rise to a certain negative impact related to 
psychological consequences: separation, emotional disturbance, depression, fatigue, exhaustion, disappointment, anger, indignation, aggression, tension and anxiety. Cynicism causes such consequences as: emotional exhaustion, loss of communication with the organization, distrust (Brandes et al., 2008), anger, shame and hopelessness (Aslan, Eren, 2014). Maslach (2003) emphasizes that namely cynicism, along with exhaustion and lack of efficacy and activeness are acknowledged as components exhausting human resources of the organization.

For these reasons, organizational cynicism leads to pessimistic, degrading and critical behavioural trends (Ozer et al., 2014). Cynicism manifests itself by negative, degrading behaviour such as: criticism towards the organization, sarcastic humour, negative non-verbal behaviour, cynical interpretations of organizational events, pessimistic predictions about the future of the organization, etc. (Dean et al., 1998). Cynicism is also related to employees' scepticism, doubts, disbelief, pessimism, negativity, lack of trust (Topcu et al., 2017). Such degrading forms of behaviour are associated with a weaker sensation that the organization has some kind of personal meaning (Naus et al., 2007a, 2007b).

Finally, various organizational problems cause monotony, anxiety and doubts (Topcu et al., 2017). U. Aslan and S. Eren (2014) as negative effects distinguish indifference, withdrawal, separation, hopelessness, distrust, and suspicion. Cynicism can be expressed by alienation and negative feelings towards a particular person, group, ideology or society, while the employees' negative attitude can be characterized as an inclination towards tendentious disappointment, critical and negative activity directed against the organization. The factors promoting organizational cynicism and their consequences for the employee-organization are detailed in Table 1.

Thus, the analysis of the causes and consequences of organizational cynicism enables to state that there are significantly more organizational factors promoting the emergence of employees' cynicism than personal factors formed by the employees' nature; therefore, it is more likely that organizational cynicism will be formed by the organizational environment. Organizational cynicism causes numerous negative consequences for employees: it is related to emotional exhaustion, which is promoted by psychological cynicism-induced problems, such as anxiety, stress, aggression, depression and physical cynicism-induced problems, such as overwork, exhaustion, etc. Organizational cynicism has a significant negative impact on the organization. Cynical employees lose motivation both with regard to work and organizational performance, which reduces the level of their effort that determines poor performance. Increased cynicism promotes alienation, negative behaviour that degrades the organisation and its performance and weak self-identification with the organization due to which employees eventually leave the organization.

\section{Dimensions of the relationship between organizational commitment and organizational cynicism}

In previous sections, we discussed the essential features of organizational commitment and organizational cynicism, the causes promoting one or another 


\section{Table 1. Summary of factors and consequences of organizational cynicism}

\begin{tabular}{|c|c|}
\hline Factors & Authors \\
\hline \multicolumn{2}{|c|}{ Organizational factors promoting organizational cynicism } \\
\hline Doubts about the organization's integrity & Dean et al., 1998; etc. \\
\hline $\begin{array}{l}\text { Excessive organizational requirements, unreasonably high salaries of } \\
\text { managers }\end{array}$ & Schraeder et al., 2016; etc. \\
\hline High level of stress & Lambert, 2004; Ozer et al., 2014; etc. \\
\hline Redundancies and high turnover of employees & $\begin{array}{l}\text { Aslam et al., 2016; Davis, Gardner, } \\
\text { 2004; etc. }\end{array}$ \\
\hline Insufficient social and organizational support, especially from managers & $\begin{array}{l}\text { Cole et al., 2006; Naus et al., 2007a, } \\
\text { 2007b; etc. }\end{array}$ \\
\hline $\begin{array}{l}\text { Insufficient promotion, unfulfilled expectations, failure to keep promises } \\
\text { of the organization, poor communication, ineffective decision-making, } \\
\text { unbalanced distribution of authority }\end{array}$ & Bommer et al., 2004; etc. \\
\hline Poor leadership skills, poor administrative competence & Cole et al., 2006; Kuang-Man, 2013; etc. \\
\hline Violation of the psychological contract & $\begin{array}{l}\text { Johnson, O’Leary-Kelly, 2003; Linde, } \\
\text { 2015; etc. }\end{array}$ \\
\hline $\begin{array}{l}\text { Role conflict, inequality, conflict of goals, high hierarchy, long working } \\
\text { hours }\end{array}$ & Davis, Gardner, 2004; etc. \\
\hline Confusing internal policy, organizational complexity and chaos & $\begin{array}{l}\text { Davis, Gardner, 2004; Ozer et al., } \\
\text { 2014; etc. }\end{array}$ \\
\hline Unethical behaviour, dishonesty, lack of justice & Dean et al., 1998; Kuang-Man, 2013; etc. \\
\hline Unsuccessful organizational changes & Ozer et al., 2014; etc. \\
\hline Distrust of leadership, leaders' hypocrisy & $\begin{array}{l}\text { Johnson, O'Leary-Kelly, 2003; Wanous } \\
\text { et al., 2000; etc. }\end{array}$ \\
\hline High competition & Dean et al., 1998; etc. \\
\hline Waste of the company's funds, lack of resources & Johnson, O'Leary-Kelly, 2003; etc. \\
\hline \multicolumn{2}{|c|}{ Personal factors promoting organizational cynicism } \\
\hline Demography & Chiaburu et al., 2013; etc. \\
\hline Previous work experience & Cole et al., 2006; etc. \\
\hline Age, sex, education & Lambert et al., 1999; etc. \\
\hline Marital status, seniority, income, professional status & Terzi, Derin, 2016; etc. \\
\hline Distrust, despair and degradation & Aslam et al., 2016; etc. \\
\hline \multicolumn{2}{|c|}{ Consequences of organizational cynicism } \\
\hline Decreased job satisfaction & $\begin{array}{l}\text { Arabaci, 2010; Terzi, Derin, 2016; Sak, } \\
\text { 2018; etc. }\end{array}$ \\
\hline Decreased commitment to the organization, loss of loyalty & $\begin{array}{l}\text { Naus et al., 2007a; Kim et al., 2009; } \\
\text { Ozer et al., 2014; etc. }\end{array}$ \\
\hline $\begin{array}{l}\text { Low level of organisational identification, low level of citizenship } \\
\text { behaviour }\end{array}$ & $\begin{array}{l}\text { Collins, 2017; Lazauskaitè-Zabielskè } \\
\text { et al., 2014; etc. }\end{array}$ \\
\hline Decreased level of effort, low level of engagement & Dean et al., 1998; Naqvi et al., 2013; etc. \\
\hline Avoiding of responsibilities, poor results & Johnson, O’Leary-Kelly, 2003; etc. \\
\hline Isolation, alienation, high turnover of employees & Brandes et al., 2008; etc. \\
\hline Loss of motivation & Collins, 2017; etc. \\
\hline Negative behaviour, degrading the organization and its activities & Dean et al., 1998; etc. \\
\hline Emotional exhaustion of employees, physical and psychological problems & Brandes et al., 2008; etc. \\
\hline
\end{tabular}


phenomenon and the consequences for the organization and the employee. Some studies demonstrate that organizational cynicism and organizational commitment have common points of relationship. For example, R. L. Volpe et al. (2014), who investigated the impact of organizational cynicism on doctors and nurses working in the US health care institutions, found that all three types of organizational cynicism (dispositional, global and local) are related to the commitment to the organization, job satisfaction, and intentions to leave a job. J. Han et al. (2013) found that organizational cynicism and organizational commitment were found to have a direct effect on turnover intention. However, in many studies, organizational cynicism and organizational commitment are dealt with separately. The comparison of the causes and consequences of both phenomena named in different studies enables to distinguish several dimensions where these phenomena have common points of relationship. These dimensions are concisely presented in Table 2.

Thus, on the one hand, organizational cynicism has a negative impact on organizational commitment by reducing it (Bernerth et al., 2007; Saleem et al., 2018), on the other hand, we see that both phenomena can affect both loyalty,

Table 2. Relationship of organisational cynicism and organisational commitment

\begin{tabular}{|c|c|c|c|}
\hline \multirow[b]{2}{*}{ Dimension } & \multirow[b]{2}{*}{ Links } & \multicolumn{2}{|r|}{ Authors } \\
\hline & & $\begin{array}{l}\text { Organizational } \\
\text { commitment }\end{array}$ & Organizational cynicism \\
\hline Loyalty & $\begin{array}{l}\text { Organizational commitment is also re- } \\
\text { lated to greater loyalty to the organiza- } \\
\text { tion, while organizational cynicism is } \\
\text { related to lesser loyalty. }\end{array}$ & $\begin{array}{l}\text { O’Reilly, Caldwell, } \\
\text { 1980; Mathieu, } \\
\text { Zajac, 1990; etc. }\end{array}$ & $\begin{array}{l}\text { Naus et al., 2007a; } \\
\text { Kim et al., 2009; } \\
\text { Ozer et al., 2014; etc. }\end{array}$ \\
\hline $\begin{array}{l}\text { Organisational } \\
\text { citizenship }\end{array}$ & $\begin{array}{l}\text { Relate through disappointment in the } \\
\text { organization. }\end{array}$ & $\begin{array}{l}\text { Ajgaonkar et al., } \\
\text { 2012; Terzi, Derin, } \\
\text { 2016; etc. }\end{array}$ & $\begin{array}{l}\text { Johnson, O'Leary-Kelly, 2003; } \\
\text { Wilkerson et al., 2008; } \\
\text { Lazauskaitė-Zabielskè et al., } \\
\text { 2014; } \\
\text { Collins, 2017; etc. }\end{array}$ \\
\hline Leadership & $\begin{array}{l}\text { Relate through leaders' behaviour and } \\
\text { ethics and support recognised in it. }\end{array}$ & $\begin{array}{l}\text { Afshari, Gibson, } \\
\text { 2016; Scott, Zweig, } \\
\text { 2016; Allen et al., } \\
\text { 2017; etc. }\end{array}$ & $\begin{array}{l}\text { Wanous et al., 2000; Johnson, } \\
\text { O’Leary-Kelly, 2003; etc. }\end{array}$ \\
\hline Job satisfaction & $\begin{array}{l}\text { While job satisfaction promotes greater } \\
\text { commitment, organizational cynicism is } \\
\text { related to lesser job satisfaction. }\end{array}$ & $\begin{array}{l}\text { Kotze, Roodt, } \\
\text { 2005; Bangval } \\
\text { et al., 2017; etc. }\end{array}$ & $\begin{array}{l}\text { Kuang-Man, 2013; Ozer et al., } \\
\text { 2014; Volpe et al. 2014; Shaha- } \\
\text { rruddin, Ahmad, 2015; etc. }\end{array}$ \\
\hline Motivation & $\begin{array}{l}\text { Negative experiences of employees } \\
\text { (tension, anxiety, dissatisfaction, anger, } \\
\text { confusion, etc.) are related to growing } \\
\text { organizational cynicism and declining } \\
\text { commitment to the organization. }\end{array}$ & $\begin{array}{l}\text { Ajgaonkar et al., } \\
\text { 2012; etc. }\end{array}$ & $\begin{array}{l}\text { Dean et al., 1998; Wanous } \\
\text { et al., 2000; Kim et al., 2009; } \\
\text { Terzi, Derin, 2016; Collins, } \\
\text { 2017; etc. }\end{array}$ \\
\hline $\begin{array}{l}\text { Quitting the } \\
\text { job }\end{array}$ & $\begin{array}{l}\text { Like organizational cynicism, declining } \\
\text { organizational commitment is related } \\
\text { to more frequent intentions to leave the } \\
\text { organization. }\end{array}$ & $\begin{array}{l}\text { Allen, Meyer, } 1990 \text {; } \\
\text { Lampinen et al., } \\
\text { 2017; etc. }\end{array}$ & Volpe et al. (2014), etc. \\
\hline
\end{tabular}


organizational citizenship and job satisfaction, motivation and intentions to leave the organization. In addition, leadership is a multidimensional factor that can both promote organizational cynicism and minimize it as well as ensure organizational commitment. As demonstrated in the study conducted by J. M. Dobbs and J. J. Do (2018), there is a link between toxic leadership and organizational cynicism. That is, persons who have traits of "toxic leaders" are more negative about their organization, demonstrating their cynical attitude. Organizational cynicism simultaneously influences lesser organizational commitment too. In other words, organizational commitment and organizational cynicism are not only closely related and interacting phenomena, but they are also variables involved in the dynamics of motivation, job satisfaction and other factors, which is important to consider conducting research.

\section{Conclusions}

Scientific literature distinguishes three main forms of organizational commitment: emotional (employees remain with the organization because they want it), continuous (employees remain in the organization because they have to do this), and normative (employees remain in the organization because they feel they must stay in it) commitments. Analysing the phenomenon of cynicism, three main forms, analysed in the research, are also distinguished: cognitive (employees feel that the organization does not care about them), emotional (encompasses negative emotional reactions) and behavioural (negative, degrading behaviour) cynicism.
Organizational commitment is described as links between the person and the organization, which can be explained by employees' behaviour that is determined by certain financial or emotional investment, or by psychological attitude, which emphasizes employees' psychological attachment. Organizational commitment is also perceived as the person's identification or the level of the person's participation in the organization, which defines the employee's trust in the organization, acknowledgement of its goals and values, and the desire to remain the member of the organization. Meanwhile, organizational cynicism is named as employees' sceptical attitude arising from a critical approach while assessing the motives, actions and values of the organization's behaviour. Such approach manifests itself by the belief that the organization does not have moral harmony and such principles as justice, honesty and sincerity are sacrificed for the sake of organizational gain. In recent years, organizational cynicism is named as a consequence and a certain way of self-defence for employees who negatively assess principles, values or actions promoted in their organization. Thus, it can be noticed that organizational commitment and organizational cynicism are related by a cause-consequence link.

Employees' cynical behaviour may emerge if employers expect from their employees more than they can give or if employers themselves do not give their employees any additional added value. Every organization itself must show its commitment to employees if it expects the same from them. Otherwise, employee cynicism, which is named as one of the most serious today's challenges for organizations, is induced. It is important to emphasise that both organizational commitment 
and organizational cynicism are related and affect various phenomena determining the organization's success, such as: organisational public spirit, organizational involvement, job satisfaction, the sense of belonging to the organization, mutual trust and assessment, open communication, open dissemination of information, assurance of meaningfulness of work, etc. Promotion of the said; i.e. positive, constituents ensures overall benefit of organizational commitment received by both the organisation and the employee. Conversely, the absence of the interaction between these phenomena determines employees' cynicism, which results in employees' negative emotions and behaviour, giving rise to negative consequences for the organisation as well. These are important points to be taken into account conducting the research dealing with loyalty, organizational citizenship, leadership, job satisfaction, motivation and circumstances of quitting the job, which should provide a complex evaluation of the links between organizational commitment and organizational cynicism and the influence on both the employee and the organization.

\section{Recommendations}

Seeking to increase employee commitment and reduce cynicism, organisations should focus on the creation of additional benefits for employees, but it is likely that the implementation of proposed solutions can be limited by time and / or financial resources of organisations. For this reason, it is proposed to the organizations to periodically carry out employees' surveys in order to identify what additional benefits are most appreciated in a particular organization, this way seeking to use resources rationally and focus primarily on the most problematic areas. Consistent data collection will enable to develop strategic ways of solving problems, this way seeking to avoid emergence of new problem situations. It is also recommended to formalize rules, provisions, standards, behaviour and various processes at the workplace, to consistently combine various measures reducing organizational cynicism and increasing organizational commitment, and to evaluate the expectations and values of newly recruited employees. It should be emphasized that the psychological contract begins with the recruitment of new employees in the organisation; therefore, it is important to ensure that the attitudes and values of new employees and the organization coincide so that it is easier to create mutual promises and later comply with them. Otherwise, both the employee and the organization will be dissatisfied with non-implementation of initial expectations. And lastly, monitoring is required organising not only, for example, annual employee assessment interviews but also regular (both formal and informal) managers' meetings with employees, discussing and evaluating how employees' attitude towards emerging challenges is changing, finding out how employees are doing at their workplaces in general. In further research, it would be meaningful to empirically test the links between loyalty, organizational citizenship, leadership, job satisfaction, motivation and quitting the job in the overall context of mutual interactions between organizational commitment and organizational cynicism. 


\section{References}

1. Abdullah, A. G. K., Almadhoun, T. Z., Ling, Y. L. (2015). Organizational Empowerment and Commitment: The Mediating Effect of Psychological Empowerment // Asian Journal of Social Sciences, Arts and Humanities. Vol. 3, No. 2, pp. 1-7.

2. Abraham, R. (2000). Organizational Cynicism: Bases and Consequences // Genetic, Social, and General Psychology Monographs. Vol. 126, No. 3, pp. 269-292.

3. Abugre, J. A. (2017) Relations at Workplace, Cynicism and Intention to Leave: A Proposed Conceptual Framework for Organisations // International Journal of Organizational Analysis. Vol. 25, No. 2, pp. 198-216. doi. org/10.1108/IJOA-09-2016-1068

4. Adams, J. S. (1963). Toward an Understanding of Inequity // Journal of Abnormal and Social Psychology. Vol. 67, pp. 422-436.

5. Afshari, L., Gibson, P. (2016). How to Increase Organizational Commitment Through Transactional Leadership // Leadership \& Organization Development Journal. Vol. 37, No. 4, pp. 507-519. doi.org/10.1108/ LODJ-08-2014-0148

6. Ajgaonkar, M., Baul, U., Phadke, S. M. (2012). Relationship between Organizational Citizenship Behavior and Job Characteristics Model of Motivation: An Empirical Study // NMIMS Management Review. Vol. 1, pp. 51-72.

7. Allen, G. W., Attoh, P. A., Gong, T. (2017). Transformational Leadership and Affective Organizational Commitment: Mediating Roles of Perceived Social Responsibility and Organizational Identification // Social Responsibility Journal. Vol. 13, No. 3, pp. 585600. doi.org/10.1108/SRJ-11-2016-0193

8. Allen, N. J., Meyer, J. P. (1990). The Measurement and Antecedents of Affective, Continuance, and Normative Commitment to the Organization // The Journal of Occupational Psychology. Vol. 63, No. 1, pp. 1-18. doi:10.1111/j.2044-8325.1990. tb00506

9. Angle, H. L., Perry, J. L. (1981). An Empirical Assessment of Organizational Commitment and Organizational Effectiveness // Administrative Science Quarterly. Vol. 26, No. 1, pp. 1-14. doi:10.2307/2392596
10. Angle, H. L., Perry, J. L. (1983). Organizational Commitment: Individual and Organizational Influences // Work and Occupation. Vol. 10, No. 2, pp. 123-146. https://doi. org/10.1177/0730888483010002001

11. Arabaci, I. B. (2010). The Effects of Depersonalization and Organizational Cynicism Levels on the Job Satisfaction of Educational Inspectors // African Journal of Business Management. Vol. 4, No. 13, pp. 2802-2811.

12. Archimi, C. S., Reynaud, E., Yasin, H. M., Bhatti, Z. A. (2018). How Perceived Corporate Social Responsibility Affects Employee Cynicism: The Mediating Role of Organizational Trust // Journal of Business Ethics. Vol. 151, No. 4, pp. 907-921. doi: 10.1007/s10551-018-3882-6

13. Aslam, U., Ilyas, M., Imran M. K., Rahman, U. (2016). Detrimental Effects of Cynicism on Organizational Change: An Interactive Model of Organizational Cynicism (a study of employees in public sector organizations) // Journal of Organizational Change Management. Vol. 29, No. 4, pp. 580-598. doi. org/10.1108/JOCM-12-2014-0231

14. Aslan, S., Eren, S. (2014). The Effect of Cynicism and the Organizational Cynicism on Alienation. -The Clute Institute International Academic Conference, Germany, pp. 268-276.

15. Bagraim, J. J. (2003). The Dimensionality of Professional Commitment // SA Journal of Industrial Psychology. Vol. 29, No. 2, pp. 6-9. https://doi.org/10.4102/sajip.v29i2.10

16. Bahrami, M. A., Barati, O., Ghoroghchian, M., Montazer-Alfaraj, R., Ezzataba, M. R. (2016). Role of Organizational Climate in Organizational Commitment: The Case of Teaching Hospitals // Osong Public Health and Research Perspectives. Vol. 7, No. 2, pp. 96100. doi.org/10.1016/j.phrp.2015.11.009

17. Basak Ok, A., Vandenberghe, C. (2016). Organizational and Career-Oriented Commitment and Employee Development Behaviors // Journal of Managerial Psychology. Vol. 31, No. 5, pp. 930-945. doi.org/10.1108/ JMP-04-2015-0157

18. Benevene, P., Dal Corso, L., De Carlo, A., Falco, A., Carluccio, F., Vecina, M. L. (2018). Ethical Leadership as Antecedent of Job Satisfaction, Affective Organizational Commitment and Intention to Stay Among Volunteers 
of Non-profit Organizations // Frontiers in Psychology. Vol. 9, Article Number: 2069. doi: 10.3389/fpsyg.2018.02069

19. Bernerth, J. B., Armenakis, A. A., Feild, H. S., Walker, H. J. (2007). Justice, Cynicism, and Commitment: A Study of Important Organizational Change Variables // The Journal of Applied Behavioral Science. Vol. 43, No. 3, pp. 303-326. doi: 10.1177/0021886306296602

20. Bernerth, J. B., Armenakis, A. A., Feild, H. S., Walker, H. J. (2007). Justice, Cynicism, and Commitment: A Study of Important Organizational Change Variables // The Journal of Applied Behavioral Science. Vol. 43, No. 3, pp. 303-326. https://doi. org/10.1177/0021886306296602

21. Bommer, W. H., Rubin, R. S., Baldwin, T. T. (2004). Setting the Stage for Effective Leadership: Antecedents of Transformational Leadership Behavior // The Leadership Quarterly. Vol. 15, No. 2, pp. 195-210. doi. org/10.1016/j.leaqua.2004.02.012.

22. Brandes, P., Castro, S. L., James, M. S. L., Martinez, A. D., Matherly, T. A. Ferris, G. R., Hochwarter, W. A. (2008). The Interactive Effects of Job Insecurity and Organizational Cynicism on Work Effort Following a Layoff // Journal of Leadership \& Organizational Studies. Vol. 14, No. 3, pp. 233-247. doi: 10.1177/1071791907311967

23. Byrne, Z. S., Hochwarter, W. A. (2008). Perceived Organizational Support and Performance: Relationships Across Levels of Organizational Cynicism // Journal of Managerial Psychology. Vol. 23, No. 1, pp. 5472. doi: 10.1108/02683940810849666

24. Caldwell, D. F., Chatman, J.A., O`Reilly, C.A. (1990). Building Organizational Commitment: A Multifirm Study // Journal of Occupational Psychology. Vol. 63, No. 3, pp. 245-261. doi: 10.1111/j.2044-8325.1990.tb00525.x

25. Cartwright, S., Holmes, N. (2006). The Meaning of Work: The Challenge of Regaining Employee Engagement and Reducing Cynicism // Human Resource Management Review. Vol. 16, No. 2, pp. 199-208. doi. org/10.1016/j.hrmr.2006.03.012

26. Chiaburu, D. S., Peng, A. C., Oh, I.-S., Banks, G. C., Lomeli, L. C. (2013). Antecedents and Consequences of Employee Organizational Cynicism: A Meta-Analysis // Journal of Vocational Behavior. Vol. 83, No. 2, pp. 181197. doi:10.1016/j.jvb.2013.03.007
27. Chin-Chih, H. (2006). A Study of the Relationships between Work Values, Job Involvement and Organisational Commitment Among Taiwanese Nurses. - A Ph.D. thesis. Australia: Queensland University of Technology.

28. Cinar, O., Karcioglu, F., Aslan, I. (2014). The Relationships Among Organizational Cynicism, Job Insecurity and Turnover Intention: A Survey Study in Erzurum/Turkey // 10th International Strategic Management Conference 2014. Edited by M. Ozsahin. Book Series: Procedia Social and Behavioral Sciences. Vol. 150, pp. 429-437. doi: 10.1016/j. sbspro.2014.09.045

29. Cole, M. S., Bruch, H., Vogel, B. (2006). Emotion as Mediators of the Relations between Perceived Supervisor Support and Psychological Hardiness on Employee Cynicism // Journal of Organizational Behavior. Vol. 27, No. 4, pp. 463-484. doi: 10.1002/job.381

30. Collins, B. J. (2017). Fair? I Don't Care: Examining the Moderating Effect of Workplace Cynicism on the Relationship between Interactional Fairness and Perceptions of Organizational Support from a Social Exchange Perspective // Journal of Leadership \& Organizational Studies. Vol. 24, No. 3, pp. 401-413. doi: 10.1177/1548051816667896

31. Cooper-Hakim, A., Viswesvaran, C. (2005). The Construct of Work Commitment: Testing an Integrative Framework // Psychological Bulletin. Vol. 131, pp. 241-259. doi: 10.1037/0033-2909.131.2.241.

32. Davis, W. D., Gardner, W. L. (2004). Perceptions of Politics and Organizational Cynicism: An Attributional and Leader-Member Exchange Perspective // The Leadership Quarterly. Vol. 15, No. 4, pp. 439-465. doi: 10.1016/j. leaqua.2004.05.002

33. Dean, J. W., Brandes, P., Dharwadkar, R. (1998). Organizational Cynicism // The Academy of Management Review. Vol. 23, No. 2, pp. 341352. doi: 10.5465/amr.1998.533230

34. Dhondt, S., Pot, F. D., Kraan, K. O. (2014). The Importance of Organizational Level Decision Latitude for Well-Being and Organizational Commitment // Team Performance Management. Vol. 20, No.7/8, pp. 307-327. doi.org/10.1108/TPM-03-2014-0025

35. Dobbs, J. M., Do, J. J. (2018). The Impact of Perceived Toxic Leadership on Cynicism 
in Officer Candidates // Armed Forces \& Society. Vol. 45, No. 1, pp. 3-26. doi: 10.1177/0095327X17747204

36. Evans, W. R., Goodman, J. M., Davis, W. D. (2011). The Impact of Perceived Corporate Citizenship on Organizational Cynicism, OCB, and Employee Deviance // Human Performance. Vol. 24, No. 1, pp. 79-97. Article Number: PII 932651540. doi: 10.1080/08959285.2010.530632

37. Faisal, M. F., Al-Esmael, B. A. (2014). Modeling the Enablers of Organizational Commitment // Business Process Management Journal. Vol. 20, No. 1, pp. 25-46. doi:10.1108/ BPMJ-08-2012-0086

38. Felfe, J. (2008). Advances in Leadership Research: The Structure of Leadership Behavior and Its Influence on Performance, Strain, Organizational Cynicism and the Role of the Context // International Journal of Psychology. Vol. 43, No. 3-4, pp. 550-550.

39. Franco, M., Franco, S. (2017). Organizational Commitment in Family Smes and Its Influence on Contextual Performance // Team Performance Management: An International Journal. Vol. 23, No. 7/8, pp. 364-384. doi:10.1108/TPM-05-2016-0020

40. Garg, N. (2017). Workplace Spirituality and Organizational Performance in Indian Context: Mediating Effect of Organizational Commitment, Work Motivation and Employee Engagement // South Asian Journal of Human Resources Management. Vol. 4, No. 2, pp. 191211. doi: org.ezproxy.vdu.lt:2443/10.1177/2322 093717736134

41. Gkorezis, P., Georgiou, L., Theodorou, M. (2018). High-Performance Work Practices and Nurses' Intention to Leave: The Mediating Role of Organizational Cynicism and the Moderating Role of Human Resource Management-Related Educational Background // International Journal of Human Resource Management. Vol. 29, No. 3, pp. 465-484. doi: 10.1080/09585192.2016.1255906

42. Gkorezis, P., Petridou, E., Xanthiakos, P. (2014). Leader Positive Humor and Organizational Cynicism: LMX as a Mediator // Leadership \& Organization Development Journal. Vol. 35, No. 4, pp. 305-315. doi: 10.1108/ LODJ-07-2012-0086

43. Gokyer, N., Turkoglu, I. (2018). The Relationship between High School Teachers' Organizational Support Perceptions and
Their Organizational Cynicism Attitudes // Egitim Ve Bilim-Education and Science. Vol. 43, No. 196, pp. 317-340. doi: 10.15390/ EB.2018.7440

44. Halbesleben, K. L., Tolbert, C. M. (2014). Small, Local, and Loyal: How Firm Attributes Affect Workers' Organizational Commitment // Local Economy. Vol. 29, No. 8, pp. 795-809. doi10.1177/0269094214556980

45. Han, J., Woo, H., Ju, E., Lim, S., Han, S. (2013). Effects of Nurses' Social Capital on Turnover Intention: Focused on the Mediating Effects Organizational Commitment and Organizational Cynicism // Journal of Korean Academy of Nursing. Vol. 43, No. 4, pp. 517525. doi: 10.4040/jkan.2013.43.4.517

46. Jena, L. K., Bhattacharyya, P., Pradhan, S. (2017). Employee engagement and Affective Organizational Commitment: Mediating Role of Employee Voice among Indian Service Sector Employees // The Journal of Business Perspective. Vol. 21, No. 4, pp. 1-11. doi:10.1177/0972262917733170

47. Jiang, S., Lambert, E. G., Jin, X., Xiang, D., Shi, M., Zhang, D. (2018). Correlates of Organizational Commitment Among Community Correctional Officers in China // The Prison Journal. Vol. 98, No. 1, pp. 60-82. doi:10.1177/0032885517743706

48. Johnson, J. L., O’Leary-Kelly, A. M. (2003). The Effects of Psychological Contract Breach and Organizational Cynicism: Not All Social Exchange Violations Are Created Equal // Journal of Organizational Behavior. Vol. 24, No. 5. pp. 627-647. doi: 10.1002/job.207

49. Karami, A., Farokhzadian, J., Foroughameri, G. (2017). Nurses' Professional Competency and Organizational Commitment: Is it Important for Human Resource Management? Plos One. Vol. 12, No. 11. Article Number: e0187863. doi: 10.1371/journal.pone.0187863

50. Kasalak, G., Aksu, M. B. (2014). The Relationship between Perceived Organizational Support and Organizational Cynicism of Research Assistants // Educational Sciences: Theory \& Practice. Vol. 14, No. 1, pp. 125-133. doi: 10.12738/estp.2014.1.1765

51. Kavaliauskienè, Ž. (2011). Darbuotojo įsipareigojimo organizacijai dimensijų ir veiksnių sąveikos. - Daktaro disertacija. Kaunas: Vytauto Didžiojo universitetas.

52. Kim, T. Y., Bateman, T. S., Gilbreath, B., Andersson, L. M. (2009). Top Management 
Credibility and Employee Cynicism: A Comprehensive Model // Human Relations. Vol. 62, No. 10, pp. 1435-1458. doi: $10.1177 / 0018726709340822$

53. Kotze, K., Roodt, G. (2005). Factors that Affect the Retention of Managerial and Specialist Staff: An Exploratory Study of an Employee Commitment Model // SA Journal of Human Resource Management. Vol. 3, No. 2, pp. 4855. doi: 10.4102/sajhrm.v3i2.65

54. Kuang-Man, W. (2013). The Effects of Psychological Contract Breach on Employee Work Behaviors in the Airline Industry: Employee Cynicism as Mediator // International Journal of Business and Social Science. Vol. 4, No. 12, pp. 304-311.

55. Lambert, E. G. (2004). The Impact of Job Characteristics on Correctional Staff Members // The Prison Journal. Vol. 84, No. 2, pp. 208227. doi: $10.1177 / 0032885504265078$

56. Lambert, E. G., Barton, S. M., Hogan, N. L. (1999). The Missing Link between Job Satisfaction and Correctional Staff Behavior: The Issue of Organizational Commitment // American Journal of Criminal Justine. Vol. 24, No. 1, pp. 95-116.

57. Lampinen, M. S., Suutala, E. A., Konu, A. I. (2017). Sense of Community, Organizational Commitment and Quality of Servines // Leadership in Health Servines. Vol. 30, No. 4, pp. 378-393. doi: 10.1108/LHS-06-2016-0025

58. Lazauskaitė-Zabielskè, J., Bagdžiūnienè, D., Rekašiūtė Balsienè, R., Urbanavičiūtè, I., Žukauskaitè, I. (2014). Darbuotojas-darbasorganizacija. Tyrimų problematika ir gairès. Metodinè priemonè. - Vilnius: Vilniaus universiteto leidykla.

59. Li, S., Chen, Y. (2018). The Relationship between Psychological Contract Breach and Employees' Counterproductive Work Behaviors: The Mediating Effect of Organizational Cynicism and Work Alienation // Frontiers in Psychology. Vol. 9, Article Number 1273. doi: 10.3389/fpsyg.2018.01273

60. Linde, B. (2015). The Value of Wellness in the Workplace: A Perspective of the EmployeeOrganisation Relationship in the South African Labour Market. Springer Briefs in Economics. - Singapore: Springer Singapore.

61. Maltin, E. R., Meyer, J. P. (2010). Employee Commitment and Well-Being: a Critical Review, Theoretical Framework and Research Agenda // Journal of Vocational Behavior.
Vol. 77, No. 2, pp. 323-337. doi: 10.1016/j. jvb.2010.04.007

62. Maslach, C. (2003). Job Burnout: New Directions in Research and Intervention // Current Directions in Psychological Science. Vol. 12, No. 5, pp. 189-192. doi. org/10.1111/1467-8721.01258

63. Mathieu, J. E., Zajac, D. M. (1990). A Review and Meta-Analysis of the Antecedents, Correlates, and Consequences of Organizational Commitment // Psychological Bulletin. Vol. 108, No. 2, pp. 171-194. doi: 10.1037/0033-2909.108.2.171

64. Memili, E., Zellweger, T. M., Fanq, H. (2013). The Determinants of Family Owners-Managers' Affective Organizational Commitment // Family Relations, Family Business Special Issue. Vol. 62, No. 3, pp. 443456. doi.org/10.1111/fare.12015

65. Mete, Y. A. (2013). Relationship between Organizational Cynicism and Ethical Leadership Behaviour: A Study at Higher Education // 2nd Cyprus International Conference on Educational Research (CYICER 2013). Edited by: Z. Ozcinar. Book Series: Procedia Social and Behavioral Sciences. Vol. 89, pp. 476-483. doi: 10.1016/j. sbspro.2013.08.880

66. Mignonac, K., Herrbach, O., Archimi, C. S., Manville, C. (2018). Navigating Ambivalence: Perceived Organizational Prestige-Support Discrepancy and Its Relation to Employee Cynicism and Silence // Journal of Management Studies. Vol. 55, No. 5, pp. 837872. doi: 10.1111/joms. 12330

67. Moon, J. S., Choi, S. B. (2017). The Impact of Career Management on Organizational Commitment and the Mediating Role of Subjective Career Success: The Case of Korean R\&D Employees // Journal of Career Development. Vol. 44, No. 3, pp. 191-208. doi: 10.1177/0894845316643829

68. Morrow, P. C. (1983). Concept Redundancy in Organizational Research: The Case Work of Commitment // The Academy of Management Review. Vol. 8, No. 3, pp. 486-500. doi. org/10.2307/257837

69. Mousa, M. (2018). The Effect of Cultural Diversity Challenges on Organizational Cynicism Dimensions: A Study from Egypt // Journal of Global Responsibility. Vol. 9, No. 3, pp. 280-300. doi: 10.1108/JGR-06-2017-0037 
70. Mueller, C. W., Boyer, E. M., Price, J. L., Iverson R. D. (1994). Employee Attachment and Noncoercive Conditions of Work // Work and Occupations. Vol. 21, No. 2, pp. 179-212. doi: 10.1177/0730888494021002002

71. Munir, Y., Ghafoor, M. M., Rasli, A. M. D. (2018). Perception of Ethical Climate and Turnover Intention Among Nursing Staff: Does Organizational Cynicism Mediate? // International Journal of Human Rights in Health Care. Vol. 11, No. 5, pp. 319-332. doi: 10.1108/IJHRH-07-2017-0028

72. Naqvi, S. R., Ishtiaq, M., Kanwal, N., Ali, M. (2013). Impact of Job Autonomy on Organizational Commitment and Job Satisfaction: The Moderating Role of Organizational Culture in Fast Food Sector of Pakistan // International Journal of Business and Management. Vol. 8, No. 17, pp. 92-102.

73. Naude, P., Desai, J., Murphy, J. (2003). Identifying the Determinants of Internal Marketing Orientation // European Journal of Marketing. Vol. 37, No.9, pp. 1205-1220. doi. org/10.1108/0390560310486951

74. Naus, A. J. A. M. (2007). Organizational Cynicism on the Nature, Antecedents and Consequences of Employee Cynicism Toward the Employing Organization. Doctoral Dissertation. Maastricht: Maastricht University.

75. Naus, F., van Iterson, A., Roe, R. (2007a). Organizational Cynicism: Extending the Exit, Voice, Loyalty, and Neglect Model of Employees' Responses to Adverse Conditions in the Workplace // Human Relations. Vol. 60, No. 5, pp. 683-718. doi: $10.1177 / 0018726707079198$

76. Naus, F., van Iterson, A., Roe, R. A. (2007b). Value Incongruence, Job Autonomy, and Organization-Based Self-Esteem: A Self-Based Perspective on Organizational Cynicism // European Journal of Work and Organizational Psychology. Vol. 16, No. 2, pp. 195-219. doi: $10.1080 / 13594320601143271$

77. Newstrom, J.W. (2015). Organizational Behavior: Human Behavior at Work. 14th Editon. - New York: McGraw Hill International Edition.

78. O’Reilly, C. A., Caldwell, D. F. (1980). Job Choice: The Impact of Intrinsic and Extrinsic Factors on Subsequent Satisfaction and Commitment // Journal of Applied Psychology. Vol. 65, No. 5, pp. 559-565. doi: 10.1037/0021-9010.65.5.559.
79. O’Reilly, C. A., Chatman, J. (1986). Organizational Commitment and Psychological Attachment: The Effects of Compliance, Identification, and Internalization on Prosocial Behavior // Journal of Applied Psychology. Vol. 71, No. 3, pp. 492-499. doi: 10.1037/0021-9010.71.3.492

80. Ozer, O., Songur, C., Kar, A., Top, M., Eriguc, G. (2014). Organizational Stress, Organizational Cynicism, Organizational Revenge, Intention to Quit: A Study on Research Assistants // The Macrotheme Review. Vol. 3, No. 8, pp. 121-128.

81. Paul, H., Bamel, U. K., Garg, P. (2016). Employee Resilience and OCB: Mediating Effects of Organizational Commitment // The Journal for Decision Makers. Vol. 41, No. 4, pp. 308-324. doi: 10.1177/0256090916672765

82. Polatcan, M., Titrek, O. (2014). The Relationship between Leadership Behaviors of School Principals and Their Organizational Cynicism Attitudes // 4th World Conference on Learning Teaching and Educational Leadership (WCLTA-2013). Edited by: J.G. Laborda. Book Series: Procedia Social and Behavioral Sciences. Vol. 141, pp. 1291-1303. doi: 10.1016/j.sbspro.2014.05.222

83. Porter, L. W., Steers, R. M., Mowday, R. T., Boulian, P. V. (1974). Organizational Commitment, Job Satisfaction, and Turnover among Psychiatric Technicians // Journal of Applied Psychology. Vol. 59, No. 5, pp. 603609. doi: 10.1037/h0037335

84. Reichers, A. E., Wanous, J. P., Austin, J. T. (1997). Understanding and Managing Cynicism about Organizational Change // The Academy of Management Executive (19932005). Vol. 11, No. 1, pp. 48-59. Internet access: http://www.jstor.org/stable/4165371

85. Rubin, R. S., Dierdorff, E. C., Bommer, W. H., Baldwin, T. T. (2009). Do leaders reap what they sow? Leader and employee outcomes of leader organizational cynicism about change // Leadership Quarterly. Vol. 20, No. 5, pp. 680688. doi: 10.1016/j.leaqua.2009.06.002

86. Sak, R. (2018). Gender Differences in Turkish Early Childhood Teachers' Job Satisfaction, Job Burnout and Organizational Cynicism // Early Childhood Education Journal. Vol. 46, No.6, pp. 643-653. doi: 10.1007/s10643-018-0895-9

87. Saleem, M. A., Yaseen, A., Zahra, S. (2018). Predictors of Organizational Commitment in Public Sector Hospitals of Pakistan-A 
Moderated Mediation Study // Journal of Health Management. Vol. 20, No. 2, pp. 206225. doi: $10.1177 / 0972063418763656$

88. Schilling, J (2008). Does Leadership Matter? Analyzing Antecedents of Organizational Cynicism // International Journal of Psychology. Vol. 43, No. 3-4, pp. 550-551.

89. Schmitz, M. A., Froese, F. J., Bader, A. K. (2018). Organizational Cynicism in Multinational Corporations in China // Asia Pacific Business Review. Vol. 24, No. 5, pp. 620-637. doi: 10.1080/13602381.2018.1492203

90. Schraeder, M., Jordan, M. H., Self, D. R., Hoover, D. J. (2016). Unlearning Cynicism: A Supplemental Approach in Addressing A Serious Organizational Malady // International Journal of Organizational Analysis. Vol. 24, No. 3, pp. 532-547. https://doi.org/10.1108/ IJOA-05-2013-0674

91. Schulz, A. A., Martin, T., Meyer, H. M. (2017). Factors Influencing Organization Commitment: Internal Marketing Orientation, External Marketing Orientation, and Subjective Well-Being // Journal of Management Development. Vol. 36, No. 10, pp. 1294-1303. doi.org/10.1108/JMD-12-2016-0334

92. Scott, K. A., Zweig, D. (2016). Understanding and Mitigating Cynicism in the Workplace // Journal of Managerial Psychology. Vol. 31, No. 2, pp. 552-569. https://doi.org/10.1108/ JMP-01-2015-0023

93. Shaharruddin, S., Ahmad, F. (2015). The Influence of Job Autonomy on Organizational Cynicism: The Reliability Test // International Journal of Research in Business Studies and Management. Vol. 2, No. 11, pp. 91-100.

94. Simha, A., Elloy, D. F., Huang, H. C. (2014). The Moderated Relationship between Job Burnout and Organizational Cynicism // Management Decision. Vol. 52, No. 3, pp. 482-504. doi: 10.1108/MD-08-2013-0422

95. Suliman, A., Iles, P. (2000). Is Continuance Commitment Beneficial to Organizations? Commitment-Performance Relationship: A New Look // Journal of Managerial Psychology. Vol. 15, No. 5, pp. 407-422. doi. org/10.1108/02683940010337158

96. Terzi, A. R., Derin, R. (2016). Relation between Democratic Leadership and Organizational Cynicism // Journal of Education and Learning. Vol. 5, No. 3, pp. 193-204. doi:10.5539/jel. v5n3p193
97. Togna, G. (2014). Does Internal Communication to Generate Trust Always Increase Commitment?: A Study at Micron Technology // Corporate Communications: An International Journal. Vol. 19, No. 1, pp. 64-81. doi: 10.1108/CCIJ-07-2012-0046

98. Topcu, I., Unaldi, N., Bacaksiz, F. E., Sen, H. T., Karadal, A., Yildirim, A. (2017). The Relationships between General and Organizational Cynicism: A Study among Healthcare Professionals // International Journal of Caring Sciences. Vol. 10, No. 1, pp. 216-224.

99. Volpe, R. L., Mohammed, S., Hopkins, M., Shapiro, D., Dellasega, C. (2014). The Negative Impact of Organizational Cynicism on Physicians and Nurses // Health Care Manager. Vol. 33, No. 4, pp. 276-288. doi: 10.1097/ HCM.0000000000000026.

100. Wanous, J. P., Reichers, A. E., Austin, J. T. (2000). Cynicism about Organizational Change. Measurement, Antecedents, and Correlates // Group \& Organization Management. Vol. 25, No. 2, pp. 132-153. doi. org/10.1177/1059601100252003

101. West, B., Hillenbrand, C., Money, K. (2015). Building Employee Relationships Through Corporate Social Responsibility: The Moderating Role of Social Cynicism and Reward for Application // Group \& Organization Management. Vol. 40, No. 3, pp. 295-322. doi: 10.1177/1059601114560062

102. Wilkerson, J. M., Evans, W. R., Davis, W. D. (2008). A Test of Coworkers' Influence on Organizational Cynicism, Badmouthing, and Organizational Citizenship Behavior // Journal of Applied Social Psychology. Vol. 38, No. 9, pp. 2273-2292. doi: 10.1111/j.1559-1816.2008.00391.x

103. Yang, Q., Lee, Y. C. (2016). Examining the Relationship between Corporate Social Responsibility, Job Satisfaction and Organizational Commitment: A Comparative Study of POSCO and Baosteel // Advanced Science Letters. Vol. 22, No. 11, pp. 3572-3576. doi: $10.1166 /$ asl.2016.7863

The paper submitted: October 15, 2018

Prepared for publication: December 10, 2018 
Aida MARGELYTĖ-PLESKIENĖ, Jolita VVEINHARDT

\section{ORGANIZACINIO İSIPAREIGOJIMO IR ORGANIZACINIO CINIZMO KVINTESENCIJA}

\section{S a n tra a k a}

Mokslinejje literatūroje išskiriamos trys pagrindinès organizacinio ịsipareigojimo formos: emocinis (darbuotojai išlieka su organizacija, nes jie to nori), tęstinis (darbuotojai lieka organizacijoje, nes jie turi tai daryti) ir norminis (darbuotojai lieka organizacijoje, nes jie jaučia, kad privalo joje pasilikti) įsipareigojimas. Analizuojant cinizmo reiškinị, taip pat išskiriamos trys pagrindinès ir šiame darbe aptariamos jo formos: kognityvinis (darbuotojai mano, kad jie nerūpi organizacijai), emocinis (apima neigiamas emocines reakcijas) ir elgesio (negatyvus, žeminantis elgesys) cinizmas.

Organizacinis îsipareigojimas apibūdinamas kaip asmens ir organizacijos ryšiai, kurie gali būti aiškinami darbuotojų elgesiu, lemiamu tam tikrų finansinių arba emocinių investicijų, arba psichologinio požiūrio, kuris akcentuoja psichologinị darbuotojų prisirišimą. Organizacinis ịsipareigojimas taip pat suvokiamas kaip asmens identifikavimas, arba asmens dalyvavimo organizacijoje lygis, kuris apibrěžia darbuotojo pasikliovimą organizacija, jos tikslų ir vertybių pripažinimą bei troškimą likti organizacijos nariu. O organizacinis cinizmas ịvardijamas kaip skeptiškas darbuotojų požiūris, kylantis dèl kritiško požiūrio vertinant organizacijos elgesio motyvus, veiksmus ir vertybes. Toks požiūris pasireiškia tikejjimu, kad organizacija neturi moralinès darnos, o tokie principai kaip teisingumas, sąžiningumas ir nuoširdumas yra aukojami dèl organizacinès naudos. Pastaraisiais metais organizacinis cinizmas ivvardijamas kaip padarinys bei tam tikras savigynos būdas darbuotojams, kurie neigiamai vertina savo organizacijoje skatinamus principus, vertybes ar veiksmus. Taigi, tarp organizacinio įsipareigojimo ir organizacinio cinizmo galima matyti priežasties - pasekmès ryšit.

Ciniško darbuotojų elgesio priežastys gali būti nulemtos, jeigu darbdaviai tikisi iš darbuotojų daugiau nei jie gali duoti arba jeigu patys darbdaviai neduoda savo darbuotojams jokios papildomos pridètinès vertès. Kiekviena organizacija pati turi rodyti savo įsipareigojimą darbuotojams, jeigu to paties tikisi iš jų. Priešingu atveju - sukeliamas darbuotojų cinizmas, kuris įvardijamas kaip vienas rimčiausių šių dienų iššūkių organizacijoms. Svarbu išskirti, kad tiek organizacinis ịsipareigojimas, tiek ir organizacinis cinizmas yra siejami ir daro poveikị ịvairiems, organizacijos sèkmę lemiantiems reiškiniams, tokiems kaip: organizacinis pilietiškumas, ịsitraukimas Ł organizaciją, pasitenkinimas darbu, priklausomybès organizacijai jausmas, tarpusavio pasitikejimas ir vertinimas, atviras bendravimas, atviras informa- cijos skleidimas, darbo prasmingumo užtikrinimas ir pan. Skatinant minètų, t. y. pozityvių, dedamųjų vystymąsi užtikrinama bendra tiek organizacijos, tiek ir darbuotojo gaunama organizacinio įsipareigojimo nauda. Ir priešingai - sąveikos tarp šių reiškinių nebuvimas lemia darbuotojų cinizmą, sukeliantị negatyvias darbuotojų emocijas bei elgesí, dèl to kyla neigiamų padarinių ir organizacijai. I tai svarbu atsižvelgti tyrimuose, nagrinejant lojalumą, organizacinị pilietiškumą, lyderystę, pasitenkinimą darbu, motyvaciją ir išejjimo iš darbo aplinkybes, kur būtų kompleksiškai ịvertintos organizacinio ịsipareigojimo ir organizacinio cinizmo sąsajos bei ịtakos.

Organizacijos, siekdamos padidinti darbuotojų ìsipareigojimą ir sumažinti cinizmą, turètų orientuotis ị papildomų naudų darbuotojams kūrimą, tačiau tikètina, kad pasiūlytų sprendimų igyvendinimą galimai gali riboti laiko ir / arba finansiniai organizacijų ištekliai. Dèl šios priežasties organizacijoms siūloma periodiškai atlikti darbuotojų apklausas tam, kad būtų nustatyta, kokios papildomos naudos yra labiausiai vertinamos konkrečioje organizacijoje, taip siekiant racionaliai panaudoti išteklius ir pirmiausia susikoncentruoti ị labiausiai problemines sritis. Nuoseklus duomenų rinkimas leis sukurti strateginius problemų sprendimo būdus, taip siekiant išvengti naujų probleminių situacijų susidarymo. Taip pat rekomenduojamas taisyklių, nuostatų, standartų, elgesio ir įvairių procesų darbo vietoje formalizavimas, nuoseklus įvairių organizacinio cinizmo mažinimo ir organizacinio ịsipareigojimo didinimo priemonių derinimas, naujai priimamų darbuotojų lūkesčių ir vertybių ịvertinimas. Akcentuotina, kad psichologinis kontraktas pradedamas it organizaciją priimant naujus darbuotojus, todèl svarbu užtikrinti, kad sutaptų naujų darbuotojų ir organizacijos požiūriai bei vertybès tam, kad būtų lengviau sukurti abipusiai ịsipareigojimai ir vèliau jų laikomasi. Kitu atveju, tiek darbuotojas, tiek organizacija bus nepatenkinti dèl pradinių lūkesčių neigyvendinimo. Ir galiausiai būtinas monitoringas, organizuojant ne tik, pavyzdžiui, metinius darbuotojų vertinimo pokalbius, bet ir reguliarius (tiek formalius, tiek ir neformalius) vadovu ir darbuotojų susitikimus, aptariant ir įvertinant, kaip keičiasi darbuotojų požiūris ị kylančius iššūkius, išsiaiškinant, kaip apskritai darbuotojams sekasi jų darbo vietose. Tolimesniuose tyrimuose būtų prasminga empiriškai patikrinti lojalumo, organizacinio pilietiškumo, lyderystès, pasitenkinimo darbu, motyvacijos ir išejjimo iš darbo sąsajas bendrame organizacinio ìsipareigojimo ir organizacinio cinizmo tarpusavio sąveikų kontekste. 